\title{
当院における院内レジオネラ感染対策部署間連携活動支援システム構築の検討
}

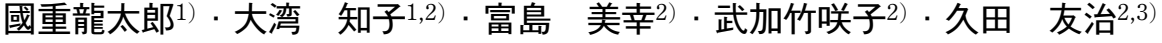 \\ 小出 道夫 ${ }^{4)} \cdot$ 健山 正男 2,4$) \cdot$ 比嘉 $\quad 太^{2,4)} \cdot$ 藤田 次郎 2,4$)$
}

\section{Promotion of Departmental Cooperative Activities Supporting the System of Legionella Infection Control in the Hospital}

\begin{abstract}
Ryutaro Kunishige ${ }^{1)}$, Tomoko Owan ${ }^{1,2)}$, Miyuki Tomisima ${ }^{2)}$, Sakiko Mukatake ${ }^{2)}$, Tomoharu KudA ${ }^{2,3)}$, Michio KoIdE ${ }^{4)}$, Masao Tateyama ${ }^{2,4)}$, Futoshi Higa ${ }^{2,4)}$ and Jiro Fujita ${ }^{2,4)}$

1) Department of Adult Nursing I, Division of Health Sciences, Faculty of Medicine, University of the Ryukyus, 2) Infection Control Room, ${ }^{3)}$ Department of Surgical Operation Center, Faculty of Medicine and University Hospital, ${ }^{4)}$ Department of Infectious, Respiratory, and Digestive Medicine, Control and Prevention of Infectious Diseases, Faculty of Medicine, University of the Ryukyus
\end{abstract}

(2014 年 5 月 14 日 受付 $\cdot 2014$ 年 9 月 12 日 受理)

\begin{abstract}
要旨
当院では浴室のシャワー水に抢けるレジオネラ調査を毎年行っている. 2010 年度では 5 階精神 科病棟浴室のシンクタップ 1 件のみにレジオネラが検出された. 2011 年度では 4 階産婦人科・周 産母子センター, NICU のシャワー, シンクタップ, 浴室以外の洗面台等水系設備の複数の箇所か らレジオネラが検出された. 対策としてホース交換と放水を長期間行ったのち再検査した結果, 1 ヶ所を除いてすべて陰性であった。聞き取り調査によると, 陽性であった周産母子センター面談室 手洗いシンクは放水による対策が十分に行われていなかった事が判明した.

今回はレジオネラ発生箇所と水系設備の配置や使用状況から, 組織連携を主とするレジオネラ対 策活動指針を考察した． 4 階は水系設備の最下層であり水が淀みやすい.さらに給水管の使用頻度 が低いためにレジオネラの検出が多くなり，レジオネラ感染症への危険性が高まると推定される. レジオネラ対策では, 給水設備の配置や水系設備の使用頻度を正しく把握する必要がある. このた め調査者は感染対策室, 該当部署, 設備課との連携と協力, 情報交換を迅速に対応することが不可 欠である。これを円滑に行えるよう支援できるシステムを構築した.
\end{abstract}

Key words : レジオネラ，感染対策，支援システム構築

\section{はじめに}

1996 年に東京都の大学病院で新生巟病棟の貯水槽や 温水タンクを経由したレジオネラ感染症による新生児の 死亡事例が 1 件発生した ${ }^{1)}$ 。この事例を受け，厚生省は レジオネラ菌に対する院内感染防止対策の推進を図るよ う各都道府県に指導し, 当院でも 1996 年 7 月から全病 院環境調査を始めた ${ }^{2-4)}$. 4 階産婦人科病棟, 6 階小児科 病棟のそれぞれ 1 ヶ所のシャワーヘッドから Legionella

1)琉球大学医学部保健学科成人看護学 I, 琉球大学医学部附属 病院 ${ }^{2}$ 感染対策室, 3) 手術部, 4) 琉球大学大学院医学研究科感 染症 $\cdot$ 呼吸器 $\cdot$ 消化器内科学講座 anisa (以下 L. anisa と表記) が検出され5), 以後モニタ リングを毎年継続している，また，全く使用していない 水系設備からはレジオネラが検出される可能性が高いと 予測し，レジオネラ対策をするように病棟担当者に指導 を行っている。

2011 年度調査では，4 階浴室換気扇が故障し 1 ヶ月 間使用していなかったため，検査結果が判明するまで使 用禁止として指導した．培養結果からレジオネラが検出 され，使用禁止の早期対策が功を奏した．使用頻度を把 握している病棟担当者と給水管・給湯管の配管設備を把 握している設備課担当者, 感染対策室専門家とレジオネ 


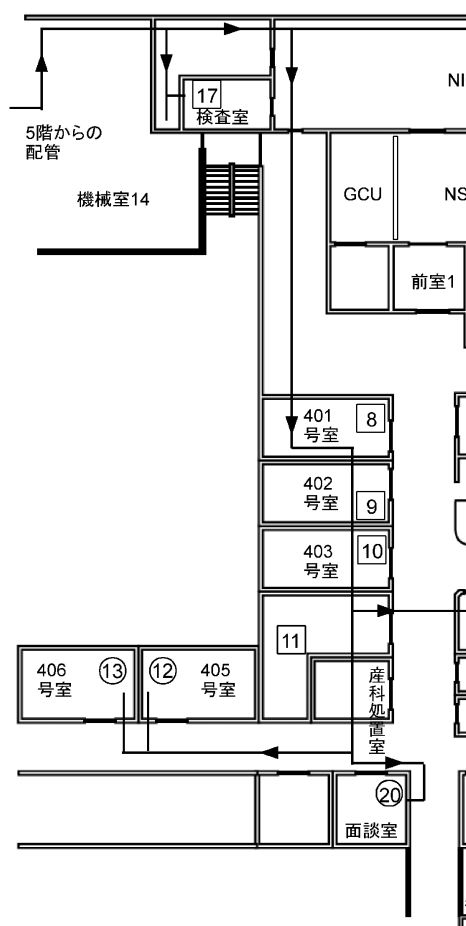

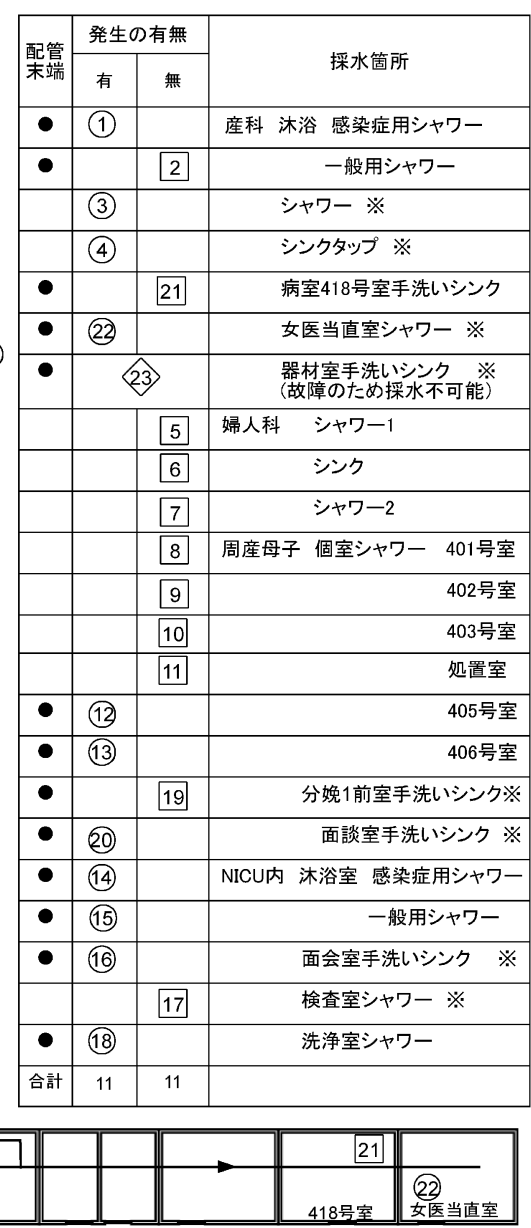

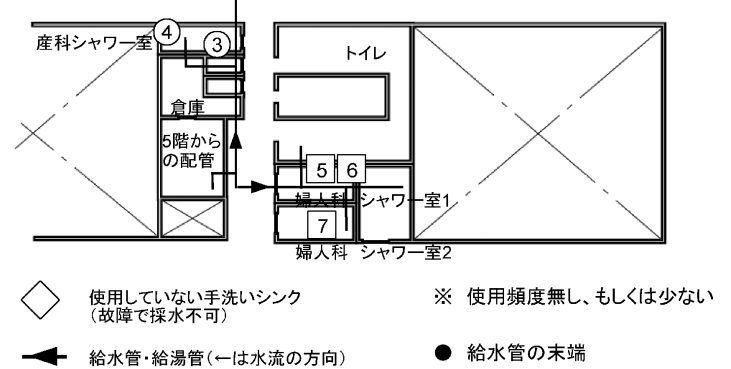

図 12011 年度 NICU · 周産母子センター・産婦人科 採水箇所

ラの調査者そして患者が連携してレジオネラ対策につい て周知徹底し，対策を行う事が重要である。

今回はレジオネラ対策が安全に行われ, 早期予防を行 えるように調査方法や対処方法に関する部署連携を支援 できる指針を作成し，レジオネラ対策システムの構築を 行った.

\section{対象及び方法}

\section{1. 採水方法 6,7$)$}

当院病棟の 1 階から 10 階の浴室シャワーとシンクタ ップを対象に行った。

病棟師長と夜勤看護師スタッフにレジオネラ対策と採 水について説明し, 消灯時間の 21 時から翌朝 5 時をで
の 8 時間 (NICU・周産母子センターは翌朝 4 時までの 7 時間) 各病棟の浴室設備の水系使用を禁止してもらっ た. 調査者は 21 時に浴室設備の扉に使用禁止を掲示し て協力依頼し, 病棟患者には病棟スタッフからの説明を 依頼した. 朝 5 時 (NICU · 周産母子センターは朝 4 時) にシャワーの初流水を $260 \mathrm{~mL}$ 用容器に採水した.

\section{Legionella 属菌分離方法 ${ }^{7-9)}$}

採水したシャワー水 $260 \mathrm{~mL}$ を $8000 \mathrm{rpm}, 20$ 分間の 冷却遠心後, 上清を取り除き, 沈殿物を再懸濁して $1 \mathrm{~mL}$ に濃縮した。これを $0.5 \mathrm{~mL}$ 採取し, $0.2 \mathrm{M} \mathrm{KCl-}$ $\mathrm{HCl}$ buffer (pH 2.2)を等量加え, 室温で 20 分間静置し て酸処理を行った. 酸処理後, その $100 \mu \mathrm{L}$ を B-CYE $\alpha$ 培地と $\mathrm{WYO} \alpha$ 培地に塗布し, $35^{\circ} \mathrm{C}, 7$ 日間培養を行っ 

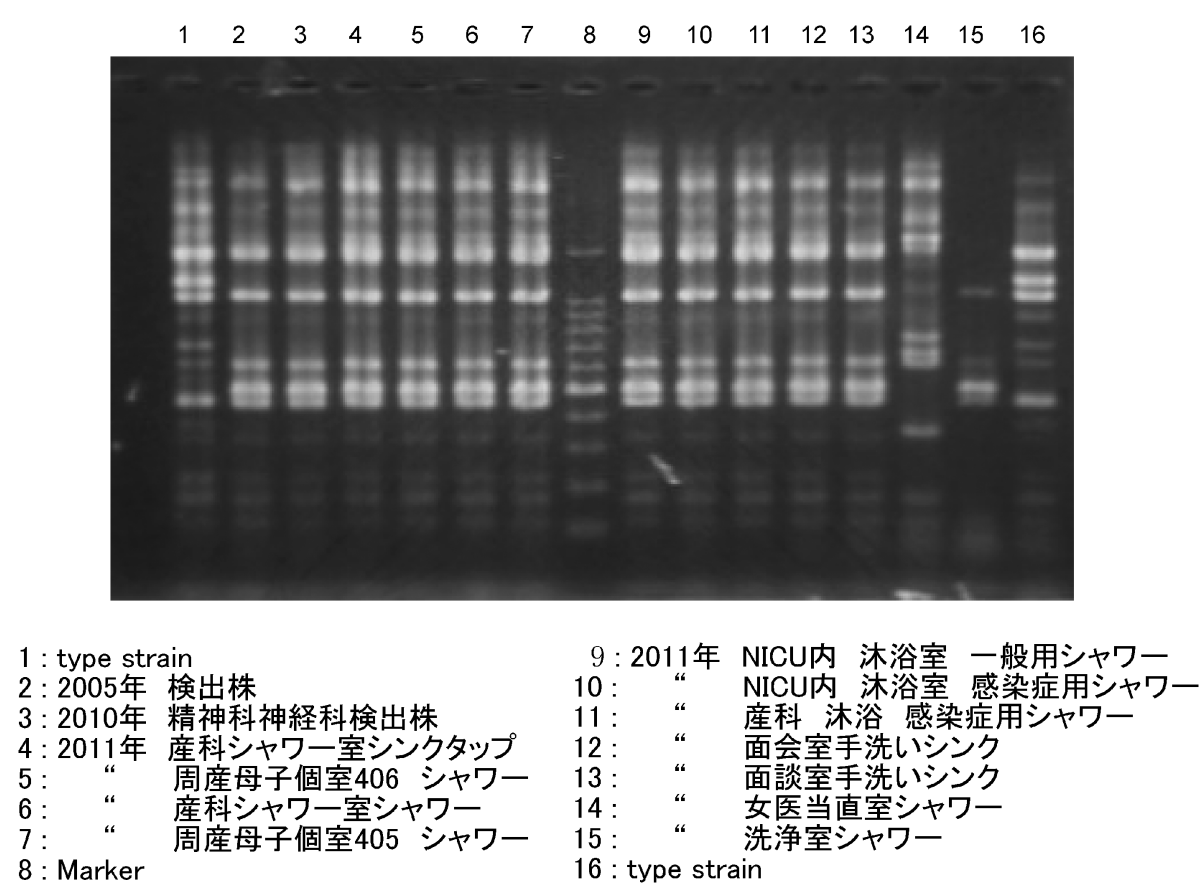

図 2 rep-PCR 法による Legionella pneumophila の遺伝子型比較

た. Legionella 属菌と疑われるコロニーは, 大小不同で 外観が灰白色・円形・浸潤である. また，バンコマイシ ン耐性を持つため, WYO $\alpha$ 培地でも発育可能である. このようにコロニー外観とバンコマイシン耐性から, 疑 わしいコロニーを選択し，通常の B-CYE $\alpha$ 培地々 Legionella の発育に必須の L- システインを含まない B$\mathrm{CYE} \alpha$ 培地, 血液寒天培地, トリプトソイ寒天培地にそ れぞれ培養を行った。 通常の B-CYE $\alpha$ 培地でコロニー 形成し, L-システインを含まない $\mathrm{B}-\mathrm{CYE} \alpha$ 培地, 血液 寒天培地, トリプトソイ寒天培地のいずれにもコロニー 形成が見られないものをLegionella と判定した.

また Legionella と判定したコロニーに紫外線を照射 し, 発光したものをL. anisa と判定した. 発光しない ものは菌種の同定で, 免疫血清 (レジオネラ免疫血清生 研, デンカ生研)によるスライド凝集反応で血清型を判 定した。

\section{3. rep-PCR 法による遺伝子型の比較}

検出された Legionella pneumophila (以下 L. pneumophila と表記) と過去に検出されたL. pneumophilaを $\mathrm{B}-\mathrm{CYE} \alpha$ 培地に塗布して $35^{\circ} \mathrm{C}$ で 4 日間培養した。培養 後現れたLegionellaのコロニーをエーゼで採取し, 滅 菌水で濃度調整し $10 \mathrm{cfu} / \mathrm{mL}$ の溶液にした。 $0.2 \mathrm{~mL}$, $10 \mathrm{cfu} / \mathrm{mL}$ の溶液をエッペンチューブに取り，QIAGEN 社の QIAamp RNA Blood Minを使ってDNA 抽 出を行った. サンプル $200 \mu \mathrm{L}$ 入ったエッペンチューブ に Buffer AL を $200 \mu \mathrm{L}$ 加えた後, プロテナーゼ $\mathrm{K} を$ $20 \mu \mathrm{L}$ ずつ加え, ボルテックスで覺拌し, $55^{\circ} \mathrm{C}$ で 15 分 間静置した. その後 $0^{\circ} \mathrm{C}, 3000 \mathrm{rpm}$ で 10 分間遠心分離
を行い，上清を新しいエッペンチューブに移し，400 $\mu \mathrm{L}$ のエタノールを加えエッペンチューブを上下にして 5〜6 回転倒混和した. スピンカラムに移して $0^{\circ} \mathrm{C}, 5000$ $\mathrm{rpm}, 1$ 分間遠心を行い, 終了後, ボトムチューブを交 換した。AW1 buffer $500 \mu \mathrm{L}$ 加えて $0^{\circ} \mathrm{C}, 5000 \mathrm{rpm}$, 1 分間遠心し，ボトムチューブを交換して， $500 \mu \mathrm{L}$ の AW2 buffer を加えて $0{ }^{\circ} \mathrm{C}, 10000 \mathrm{rpm}, 10$ 分間, 遠心 分離した.

ボトムチューブをエッペンチューブに交換して, $\mathrm{AE}$ bufferを $200 \mu \mathrm{L}$ 加え 15 分間静置する. その後 $0{ }^{\circ} \mathrm{C}$, $8000 \mathrm{rpm}$ で 5 分間, 遠心分離した。 上記の方法で精製 した各 Legionella の DNA を rep-PCR を行った. プラ イマーは Rep-1, 2 を $2.5 \mu \mathrm{L}$ ずつ，サンプルを $2.5 \mu \mathrm{L}$ ， DNAMixture を $40 \mu \mathrm{L}$ を加えて全量を $50 \mu \mathrm{L}$ にした。

\section{これにミネラルオイルを 2 滴加えた.}

$\mathrm{PCR}$ はイニシャルを $95^{\circ} \mathrm{C}$ で 7 分間, 熱変性ステップ は $90^{\circ} \mathrm{C}$ で 30 秒間, アニーリングステップは $40^{\circ} \mathrm{C}$ で 1 分間，伸長ステップを $65^{\circ} \mathrm{C}$ で 8 分間，ファイナルは 65 ${ }^{\circ} \mathrm{C}$ で 16 分間, 反応サイクルは 35 回で行った. PCR 終 了後, 生成物 $10 \mu \mathrm{L}$ を $3 \%$ アガロースゲル, $1 \times \mathrm{TBE}$ buffer で電気泳動を行った。電気泳動は $50 \mathrm{~V}$ で 60 分 間行った. 電気泳動終了後, アガロースゲルをエチジウ ムブロマイドに浸漬後, 45 分間染色を行った. 染色終 了後UVライトボックス上で観察, 画像取り込みを行 い比較した.

\section{4. 水系施設の給水·給湯系の構造}

10 階建ての病院の給水配管は 3 階から 1 階までと, 10 階から 4 階(最下階) までの 2 つ配管である.ささに 4 
表 12010 年度-2011 年度 当院水系のレジオネラ調査

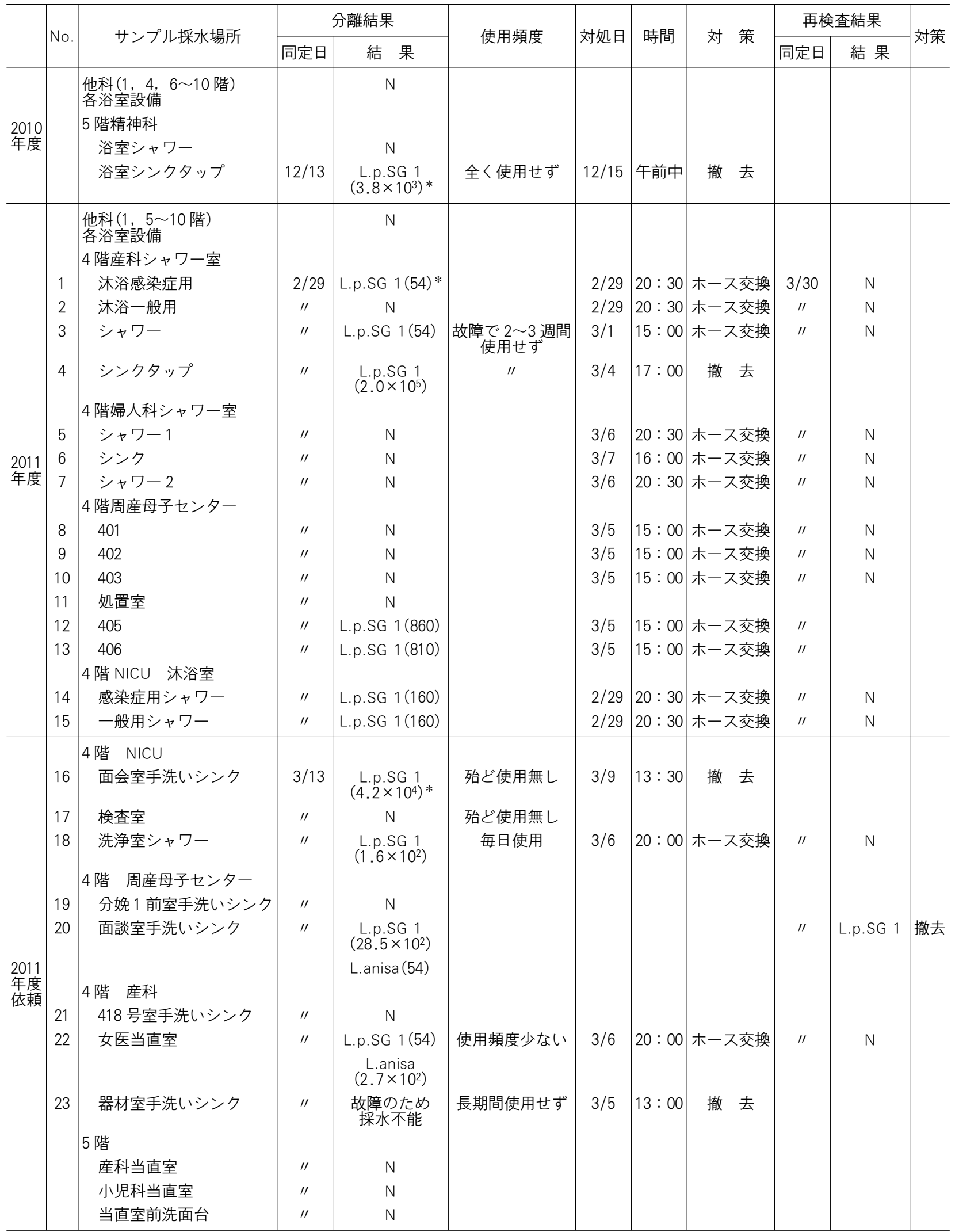

*：（）数字は colony forming units $/ 100 \mathrm{~mL}$. N : 陰性, L.p.SG 1 : L.pneumophila serogroup 1. 
表 2 レジオネラ対策における連携

\begin{tabular}{|c|c|c|c|c|}
\hline 感染対策過程 & 調 査 者 & 病 棟 担 当 & 設 備 担 当 & 感染対策室 \\
\hline 常 時 & $\begin{array}{l}\text { (1)検出の可態性がある箇所 } \\
\text { は防対策指導 }\end{array}$ & $\begin{array}{l}\text { (1)初流水を使用しない } \\
\text { (2)末端蛇口゙シャワーロで } 20 \\
\text { 分間放 水 } 5 \text { 分間, } 55^{\circ} \mathrm{C} \\
\text { 以上熱湯 } 5 \text { 分間) } \\
\text { (3)使用低頻度の水系設備は毎 } \\
\text { 朝放水 } \\
\text { (4)使用していない手洗いシン } \\
\text { クを撤去 }\end{array}$ & $\begin{array}{l}\text { (1)末端蛇口で給湯系は } 50^{\circ} \mathrm{C} \\
\text { 以給水系は } 20^{\circ} \mathrm{C} \text { 人下 } \\
\text { に維持 } \\
\text { (2)残留塩素濃度を } 0.1 \sim 0.2 \\
\text { ppm に保 } \\
\text { (3)水系設備の故㜔個所に早急 } \\
\text { に対柋して交換部品確保 }\end{array}$ & $\begin{array}{l}\text { ICT 会議 } \\
\text { 感染対策実務者会議 } \\
\text { 感染対策委員会 }\end{array}$ \\
\hline 検査前 & $\begin{array}{l}\text { (1) } 21 \text { 時〜 } 5 \text { 時迄水使用禁止 } \\
\text { を病棟告知 } \\
\text { (2)調查籄所の使用頻度.状 } \\
\text { 桬把握(使用した時は調 } \\
\text { 査延期) }\end{array}$ & $\begin{array}{l}\text { (1)21 時〜5 時迄水使用禁止を } \\
\text { 患者掲示 } \\
\text { (2)調查箇所使用時は調査者へ } \\
\text { 報告 }\end{array}$ & & \\
\hline 検査時 & 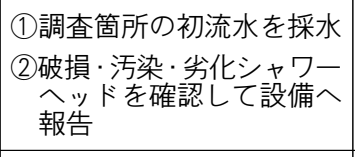 & $\begin{array}{l}\text { 設備へ破損·污染·劣化シャ } \\
\text { 交換依頼 }\end{array}$ & $\begin{array}{l}\text { 破損·污染·劣化シャワーへ } \\
\text { ッ交換 }\end{array}$ & \\
\hline 検査中 & $\begin{array}{l}\text { レジオネラ発生疑い時に水 } \\
\text { 采使用を控えるうう病棟に } \\
\text { 報告 }\end{array}$ & & & \\
\hline 検出時 & $\begin{array}{l}\text { (1)感染対策室へ報告 } \\
\text { (2) シャワーへッドとホース } \\
\text { 效換の確認と培養検査 } \\
\text { (3)手洗いシンク設備撤去の } \\
\text { 確認 }\end{array}$ & 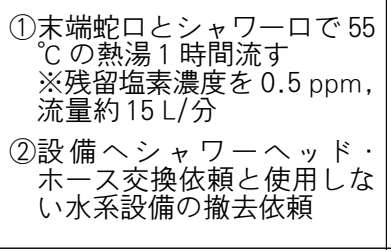 & $\begin{array}{l}\text { (1) 渙 } \\
\text { 換 } \\
\text { (2)使用頻度を高める指導 } \\
\text { (3)給水管撤去の判断依頼 } \\
\text { (4)水系設備の塩素濃度再検査 } \\
\text { (5)水系設備配管の再確認 }\end{array}$ & $\begin{array}{l}\text { 病棟·設備·調査者と緊 } \\
\text { 急会議開集を行うジオ } \\
\text { 対策指導を }\end{array}$ \\
\hline 検出後 & $\begin{array}{l}\text { シャワーへッドとホースの } \\
\text { 交換, 設備撤去, 放水後に } \\
\text { 再調査 }\end{array}$ & & & $\begin{array}{l}\text { ICT 会議報告 } \\
\text { 感染対策実務者会議報告 } \\
\text { 感染対策委員会報告 }\end{array}$ \\
\hline
\end{tabular}

階では NICU · 周産母子センターと産科・婦人科では配 管が別れており，給湯系の配管も給水系と同様であった (図 1).

\section{結果}

\section{1. 環境培養}

L. pneumophila serogroup 1 type strain Philadelphia 1 (以下 type strain と表記) と 2005 年に環境から検出され たL. pneumophila, 今回検出されたL. pneumophilaを rep-PCR 法で比較した (図 2).この結果より, type strain とは 2005 年度, 2010 年度, 2011 年度の環境下 より検出されたL. pneumophila は異なった. しかし, 女医当直室シャワー, 洗浄室シャワーで検出された $L$. pneumophila を除いて, 2005 年度, 2010 年度, 2011 年 度の環境下より検出されたL. pneumophila は全て同じ であった。

\section{2. 水系施設の使用頻度調査と対策}

\section{1） 2010 年度レジオネラ対策}

2010 年度には 5 階精神科神経科病棟の浴室内にある シンクタップは全く使用されていない情報を病棟担当の 看護スタッフより収集できた.シンクタップから L . pneumophila serogroup 1 が検出され, 看護師長が設備 課に依頼し，シンクタップの撤去を行った. その後，5 階浴室水系設備の再検査を行ったが，レジオネラは検出 されなかった。

\section{2） 2011年度レジオネラ対策}

2011 年度では 4 階産科浴室の換気扇故障のため水系 設備を 1 ヶ月間使用していない事が採水時に分かっ た.このため, 病棟の看護師長と夜間看護師にレジオネ ラが検出される可能性が高い事を告げ，浴室を使用しな いよう指導した．また，滞留がないよう常に放水するこ とを指導した。検査の途中経過報告時にもレジオネラの 矤予いがある箇所は，使用前の放水を行い滞留水が残らな いようにすることを病棟の看護師長と看護スタッフに連 絡した.

検査結果，4 階産科沐浴室の感染患者用のシャワー設 備, 産科浴室のシャワー設備とシンクタップ設備, 周産 母子センター内の 405 号室と 406 号室の浴室シャワー 設備, NICU 内沐浴室の感染症用シャワー設備と一般用 シャワー設備から L. pneumophila serogroup 1 が検出さ れた. 19 時, 判明してから直ちに ICD 3 名, 専従 ICN 2 名, 設備課 1 名, 調査者 3 名が集まり緊急対策会議を 
開き対策した. 直ちに 406 号室の入院患者を別室に移 動し, 全ての空部屋のシャワー設備を 1 時間放水し, シャワー内の塩素濃度が低い滞留水を排出した. さらに $55^{\circ} \mathrm{C}\left(\right.$ 施設のシャワー最大温度が $55^{\circ} \mathrm{C}$ )の温水を 1 時間 放水した。 また当日交換可能なシャワーホース・ヘッド の交換を行った．別日に在庫部品の無いシャワーホー ス・ヘッドと使用頻度の低い設備の撤去を行った（表 1). また設備課と連携して, 給水・給湯の配管を確認 し，レジオネラ発生箇所と照合した(図 1).

翌日午前中に当該部署の代表者 2 名(産科医 1 名, 小 児科医 1 名), ICD 3 名, 専従 ICN 2 名, 調査者(兼任 ICN 1 名, レジオネラ専門教員 1 名), 病棟師長, 設備 課 1 名が集まり 2 回目の緊急追加会議を行い, 4 階浴室 設備の検查済み箇所以外の使用頻度が低い水系設備にお けるレジオネラ検査が決定された.

新たに依頼された調査の結果, NICU 面会室の手洗い シンク, NICU 洗浄室のシャワー設備, 産科女医当直室 のシャワー設備, 周産母子センターの面談室の手洗いシ ンクから L. pneumophila serogroup 1 が検出された。ま た, 産科女医当直室のシャワー設備, 周産母子センター の面談室の手洗いシンクからはL. anisa も検出され た. 依頼調査箇所のうち, NICU 洗浄室と産科女医当直 室はシャワーホースとシャワーヘッドの交換, 面会室の 手洗いシンクは撤去となった。 また使用していない産科 器材室の手洗いシンクは故障のため採水できず依頼検査 ができなかったが，滞留水の原因になるため撤去した。 シンク撤去時には枝配管も取り除き滞留水が出来ないよ うにした。なお，検査箇所および対策を表にまとめた (表 1).

\section{考察}

環境培養結果として L. pneumophila の比較から女医 当直室シャワー, 洗浄室シャワーで検出された L. pneumophila を除いて, 2005 年度, 2010 年度, 2011 年度の 環境下より検出された L. pneumophila は全て同じであ った. 従って, 2005 年度に発生したL. pneumophila が 現在まで当病院の配管内に残っている可能性が考えられ る.さらに 2010 年度には 5 階環境下より検出された $L$. pneumophila と 2011 年度の 4 階環境下より検出された L. pneumophilaの遺伝子型が同じと考えられるため, 4 階から 5 階までレジオネラが拡散している可能性も考 えられる.

水系施設の使用頻度調査より, 換気扇が故障して修理 されず，長期間使用されていない箇所からL. pneumophila serogroup 1 が多く検出される前に設備課が換気扇 の早急な修理を行っているか, 病棟担当者が換気扇の故 障があってもシャワーを定期的に放水していれば，浴室 からの発生を未然に防げたと考えられる. また, 使用目

\begin{tabular}{|c|c|c|}
\hline 検査場所 & [ ]階 $[$ ]病棟 & \multirow{2}{*}{ 採水者氏名 [} \\
\hline 採水日 (月/日) & 年 月 日 & \\
\hline \multirow{7}{*}{ 使用状況 } & 使用頻度 & $\begin{array}{l}\square \text { 毎日 } \square 2 \text { 日に一回程度 } \\
\square \text { 一週間に一回程度 } \\
\square \text { 使用せず } \\
\square \text { その他 ( ) }\end{array}$ \\
\hline & シャワーヘッド & $\begin{array}{l}\square \text { 変色 } \square \text { 劣化 } \square \text { 破損 } \\
\square \text { その他( }\end{array}$ \\
\hline & ホース & $\begin{array}{l}\square \text { 変色 } \square \text { 劣化 } \square \text { 破損 } \\
\square \text { その他( }\end{array}$ \\
\hline & カラン & $\begin{array}{l}\square \text { 変色 } \square \text { 劣化 } \square \text { 破損 } \\
\square \text { その他( }\end{array}$ \\
\hline & 換気扇 & $\begin{array}{l}\square \text { 変色 } \square \text { 劣化 } \square \text { 破損 } \\
\square \text { その他( }\end{array}$ \\
\hline & その他 & ( \\
\hline & 〈浴室概略図 破損 & 箇所を図示〉 \\
\hline $\begin{array}{l}\text { 病棟への } \\
\text { 対策指導 }\end{array}$ & 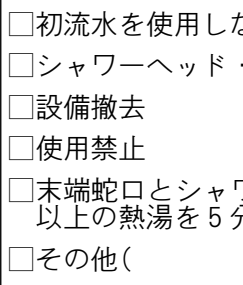 & $\begin{array}{l}\text { ないよう指導 } \\
\text { •ホースの交換 } \\
\text { ・ーロで水を } 5 \text { 分間, } 65 \text { 度 } \\
\text { 分間(合計 } 20 \text { 分間)を流す。 }\end{array}$ \\
\hline 施設課への連絡 & $\begin{array}{l}\square \text { 塩素濃度の調査 } \\
\square \text { シャャワーヘッド. }\end{array}$ & $\begin{array}{l}\square \text { 設備撤去 } \\
\text { ホース交換 }\end{array}$ \\
\hline & 口その他( & ) \\
\hline 給水管·給湯管 & $\begin{array}{l}\text { 配管ルート確認(有 } \\
\text { 配管ルート確認(有 } \\
\text { 配管の老朽化(有 } . \\
\text { 配管の老朽化(有. } \\
\text { その他( }\end{array}$ & $\begin{array}{l}\cdot \text { 無） } \\
\text { ·無） } \\
\text { 無） } \\
\text { 無） }\end{array}$ \\
\hline 追加調査依頼 & $\begin{array}{l}\square \text { 有り 調査箇所 }[ \\
\text { 依頼者 }[ \\
\square \text { 無し } \square \text { その他 }\end{array}$ & ] 日付 [ \\
\hline 確認サイン & 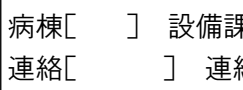 & 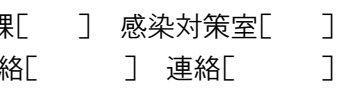 \\
\hline
\end{tabular}

的が変更された部屋の水系設備も同様の対策か設備の撤 去を行う事が必要であったと考える。このように，レジ オネラの予防策として病棟と設備課の連携は重要であ る. また, 実際に検出した後もシャワー・蛇口等の水系 設備交換と撤去, 給水と給湯の配管の考察など病棟と設 
備課, 調査者, 感染対策室の連携は必要になる。これら の予防と対策に抢ける連携を示した(表 2). さらに再検 査で, 周産母子センター面談室手洗いシンクより L. pneumophila serogroup 1 が再度検出されたため, 病棟 スタッフより情報収集したところ, 放水が十分でない事 が判明し，病棟スタッフが対策を明確に理解しているこ とを確認する必要性がある。

水系施設の構造などを含む情報を共有しやすくするた めにチェックリストを考案した (表 3). 今後の課題とし て実際活用出来るようにする.

レジオネラ感染対策とは, 感染対策室や病棟担当者な どの医療従事者だけが理解していれば良い訳では無い。 今回の調査でも設備課や患者, 部署管理者の協力も必要 であった.つまり病院という施設に関わるもの全員が理 解して取り組まなければ効果的に行われず，患者や作業 員の安全確保もできない。このため, 医療従事者以外へ の感染対策の指導も必要である. そして，各部署のスタ ッフが交代する事になっても円滑に感染対策が行われる ように，継続的教育も必要であり，その中心的な役割を 果たす事が感染対策室に求められる. 今後拡散を抑える ために, 再度院内の使用頻度の低い水系設備のモニタリ ングと, 定期的な放水やフラッシング等の対策が重要で ある。

今回作成した資料を医療従事者への指導ツールとして 実際に活用し, 調査結果の綿密な報告と共に他部署同士 の情報共有化と連携強化につながるよう提言したい.
謝 辞 : 本研究の調査にご協力頂きました, 病棟の医師, 看護 師, 施設課, 感染対策室の職員の皆様に心から深謝いたします.

利益相反について : 利益相反はない.

\section{文献}

1）長岡常雄：慶応義塾大学病院レジオネラ症対策報告書 貯水・貯湯槽の衛生管理の徹底を.月刊ビルメンテナン 又 2010; 31(12): 41-3.

2）斎藤 厚：わが国におけるレジオネラ感染症の特徵と世 界の動向. 日内会誌 2003; 92: 1662-72.

3）斎藤 厚, 草野展周, 健山正男, 大湾知子 : レジオネラ 症. 日本環境感染学会監修: 病院感染防止マニュアル. オフィスエム・アイ・ティ, 東京, 2001, p. 16.

4）厚生労働省告示第二百六十四号 レジオネラ症を予防す るために必要な措置に関する技術上の指針．2003.

5）小出道夫, 藤田次郎：レジオネラによる院内感染と感染 防止対策．環境感染誌 2009; 24(1): 1-8.

6）仲宗根力, 山本夏男, 新里 敬, 久保田徹, 比嘉 太, 健山正男, 他 : 琉球大学医学部附属病院に抢けるシャ ワー水のレジオネラ追跡調査. 環境感染 2003; 18: 131.

7）鈴木真理江, 大湾知子, 高良武博, 小出道夫, 齋藤 厚 : 看護演習室シャワーユニットにおける Legionella に 関する調查と対策. 平成 15 年度琉球大学医学部保健学 科卒業研究論文集 2004; 31: 73-6.

8) 斎藤 厚：レジオネラ感染症ハンドブック．日本医事新 報社, 東京, 2007 .

9）小川 博(厚生省生活衛生局企画課監修)：新版レジオネ ラ症防止指針．ビル管理教育センター，東京，1999.

〔連絡先：干903-0215 沖縄県西原町字上原 207 番地 琉球大学医学部保健学科成人看護学 I 國重龍太郎 E-mail:eg001k8@c-able.ne.jp] 


\title{
Promotion of Departmental Cooperative Activities Supporting the System of Legionella Infection Control in the Hospital
}

\author{
Ryutaro Kunishige ${ }^{1)}$, Tomoko OWAN ${ }^{1,2)}$, Miyuki Tomisima ${ }^{2)}$, Sakiko MukATAKE ${ }^{2)}$, Tomoharu KudA ${ }^{2,3)}$, \\ Michio KoIde ${ }^{4)}$, Masao Tateyama ${ }^{2,4)}$, Futoshi $\mathrm{Higa}^{2,4)}$ and Jiro Fujita ${ }^{2,4)}$ \\ 1) Department of Adult Nursing I, Division of Health Sciences, Faculty of Medicine, University of the Ryukyus, \\ ${ }^{2)}$ Infection Control Room, ${ }^{3)}$ Department of Surgical Operation Center, Faculty of Medicine and University Hospital, \\ ${ }^{4)}$ Department of Infectious, Respiratory, and Digestive Medicine, Control and Prevention of Infectious Diseases, Faculty of \\ Medicine, University of the Ryukyus
}

\begin{abstract}
In our hospital, Legionella monitoring in the shower water of bathrooms is conducted every year. Legionella was detected in only one of the sink taps of the fifth floor psychiatric ward bathroom in 2010, but Legionella was also detected in several showers and sink taps of the fourth floor obstetrics and gynecology ward, Maternity and Perinatal Care Center, and NICU in 2011. Furthermore, L. pneumophila serogroup 1 was detected in several components of the water system equipment except for bathrooms. Hoses were exchanged and water drained to eradicate Legionella, and rechecking was negative in all locations except the sink of the interview room in the Maternity and Perinatal Care Center. According to interviews with nurses, water drainage was not fully performed. We considered the departmental cooperative activities supporting the system of Legionella infection control in the hospital, and the arrangement and use of water system equipment at this time. We thought that the risk of Legionella becomes high with low frequency in use of water system equipment, because the infection center was on the fourth floor that is the bottom of the arrangement of water system equipment, and infection spread mostly from water system equipment with low frequency use in that location. The arrangement of a water supply system must be carefully examined, and the frequency of use of water system equipment monitored as part of measures against Legionella. For this reason, prompt cooperation between the infection control committee, responsible staff, and the equipment division, and information exchange are essential. We propose a guidance plan to ensure cooperation and exchange of information.
\end{abstract}

Key words : Legionella, infection control, supporting system structure 